\title{
Analisis Willingness to Pay dan Pengaruh Variabel Pendapatan, Jumlah Tanggungan Rumah Tangga, Usia, Akses ke Sekolah Terhadap Pemilihan serta Pengembangan Strategi Pengelolaan Sekolah
}

\author{
Christina Whidya Utami, Metta Padmalia \\ Universitas Ciputra \\ e-mail:whidyautami@ciputra.ac.id,metta.padmalia@ciputra.ac.id
}

\begin{abstract}
The purpose of this study is to estimate and analyze the willingness to pay and fax tor the factors that affect the willingness to pay at high school in Semarang. The method used is contingent valuation method (CVM) and multiple linear regression analysis. The number of samples in this study were 238 respondents, the sampling technique was done by snowball sampling. The results of this study indicate that the average willingness to pay (WTP) of households in high schools in Semarang is Rp559.034,00. Factors that have a significant influence on WTP values are income variables, number of household dependents, age, and length of access. Whereas the factors that have no effect on willingness to pay (WTP) are parents' education variables. Based on the results of the study, the suggestions that can be put forward are the management or the government to improve the quality of the vocational school as well as the development of a transparency policy on the collection and allocation of user fees and other resources.
\end{abstract}

Keywords: willingness to pay, income variables, number of household dependents, age and length of access

\section{PENDAHULUAN}

Era globalisasi lebih menuntut kesiapan yang matang dalam segala aspek, termasuk dalam bidang pendidikan yang merupakan salah satu andalan untuk mempersiapkan sumber daya manusia yang dibutuhkan untuk menghadapi tantangan zaman. Persiapan sumber daya manusia dalam bidang pendidikan dilakukan sejak dari masa pendidikan sekolah dasar, menengah pertama, hingga menengah atas. Setiap level sekolah merupakan lembaga tempat anak didik memperoleh pendidikan dan pelajaran yang diberikan oleh para pendidik. Sekolah mempersiapkan anak didiknya agar mendapatkan ilmu pengetahuan, keterampilan, budi pekerti, dan meningkatkan ketakwaaan kepada Tuhan Yang Maha Esa sebagai bekal hidup di masyarakat.

Pendidikan merupakan salah satu kunci dari kemajuan suatu bangsa. Pendidikan merupakan sarana yang sangat penting dalam membangun sumber daya manusia, karena dengan pendidikan maka akan ada pembangunan. Kota Semarang sebagai Ibu Kota Provinsi Jawa Tengah juga diharapkan dapat berperan sebagai pusat pendidikan. Khususnya pendidikan sekolah menengah atas di wilayah Jawa Tengah.

Di sisi lain, tujuan utama pembangunan ekonomi adalah untuk menciptakan pertumbuhan dan peningkatan sumber daya manusia. Seiring dengan berkembangnya teori human capital semakin terlihat bahwa pendidikan memegang peranan penting dalam menentukan kualitas tenaga kerja dan pada akhirnya akan memengaruhi pendapatan dan produktivitas kerja (Nihayah \& Kusmantoro, 2010). Tujuan penyelenggaraan pendidikan menengah yang sering disebut dengan sekolah menengah atas (SMA) harus multi-fungsi dan saling terkait. 
Fenomena ini juga terjadi di Pulau Jawa yaitu jumlah SMA dan jumlah siswa SMA setiap tahunnya mengalami peningkatan. Bertambahnya jumlah sekolah menengah atas dan siswanya karena Pulau Jawa merupakan pusat pertumbuhan ekonomi di Indonesia. Berdasarkan data yang diperoleh dari BPS tahun 2017 dapat disimpulkan bahwa jumlah sekolah menengah atas di Pulau Jawa mengalami peningkatan dari tahun ke tahun. Pada tahun 2011/20 jumlah SMA hanya 5.764 kemudian meningkat 25,72\% menjadi 7.274 pada tahun 2015/2016 (BPS, 2017). Peningkatan jumlah SMA tersebut tentunya bertujuan untuk mewujudkan program pemerintah yaitu menurunkan angka pengangguran. Pengangguran masih menjadi masalah serius di Indonesia karena hampir seluruh wilayah di Indonesia mengalami masalah yang sama di bidangnya seperti pengangguran, terutama pengangguran berpendidikan. Demikian juga seperti yang ditunjukkan dalam Tabel 1, jumlah SMA dibandingkan dengan SMK pada 10 provinsi yang memiliki SMA dan SMK terbesar di Indonesia.

Tabel 1 Jumlah SMA dan SMK di Indonesia Tahun 2017/2018 pada 10 Provinsi Terbanyak

\begin{tabular}{|l|r|r|}
\hline \multicolumn{1}{|c|}{ Provinsi } & \multicolumn{1}{c|}{ SMA } & \multicolumn{1}{c|}{ SMK } \\
\hline Jawa Barat & 1584 & 2846 \\
\hline Jawa Timur & 1524 & 1983 \\
\hline Jawa Tengah & 858 & 1569 \\
\hline Sumut & 1064 & 978 \\
\hline Banten & 529 & 668 \\
\hline DKI Jakarta & 502 & 579 \\
\hline Sulsel & 582 & 435 \\
\hline Lampung & 484 & 457 \\
\hline Sumsel & 594 & 294 \\
\hline
\end{tabular}

Sumber: BPS Jawa Tengah, 2019

Berdasarkan data yang diperoleh dari BPS tahun 2017 dapat disimpulkan bahwa jumlah siswa SMA di Jawa dari tahun 2011/2012 hingga
2015/2016 terus meningkat walaupun pada tahun 2014/2015 jumlah siswa SMA menurun namun pada tahun 2015/2016 mengalami peningkatan lagi. Pada tahun 2011/2012 jumlah siswa SMA hanya 2.498 .091 meningkat $11,21 \%$ menjadi 2.778.204 pada tahun 2015/2016 (BPS, 2017). Hal tersebut menunjukkan adanya minat masyarakat untuk melanjutkan ke jenjang pendidikan yang lebih tinggi.

Kota Semarang memiliki posisi geostrategis sebagai Kota Pusat Pemerintahan Provinsi Jawa Tengah, karena berada pada jalur lalu lintas ekonomi Pulau Jawa dan merupakan koridor pembangunan Jawa Tengah yang terdiri dari empat simpul pintu gerbang. Kota Semarang memiliki luas wilayah sebesar $373,70 \mathrm{~km}^{2}$ yang lokasinya berbatasan langsung dengan Kabupaten Kendal di sebelah Barat, Kabupaten Semarang di sebelah Selatan, Kabupaten Demak di sebelah Timur, dan Laut Jawa di sebelah Utara dengan panjang garis pantai berkisar 13,6 km.

Jumlah warga Semarang terus meningkat, pada 2012 populasinya hanya 1.559 .198 kemudian meningkat $11,98 \%$ menjadi 1.729 .428 pada tahun 2016 (BPS, 2017). Peningkatan jumlah penduduk juga diikuti oleh laju pertumbuhan penduduk yang cenderung meningkat dan laju pertumbuhan ekonomi yang fluktuatif. Laju pertumbuhan penduduk meningkat 0,70\% selama 2012-2016, dari 0,96\% menjadi 1,66 persen, sedangkan laju pertumbuhan ekonomi tahun 2016 sebesar 5,69\%. Angka ini menurun dibandingkan tahun sebelumnya. Penurunan laju pertumbuhan ekonomi Kota Semarang pada tahun 2016 masih di atas laju pertumbuhan ekonomi di Jawa Tengah yang hanya sebesar 5,28\% sekaligus masih menjadi penopang utama laju pertumbuhan ekonomi Jawa Tengah. Laju pertumbuhan ekonomi Kota Semarang memberikan kontribusi terbesar terhadap pertumbuhan ekonomi di Jawa Tengah yaitu sebesar 13,45\% (BPS, 2017), tahun 
Christina W.U., Metta P., Analisis Willingness to Pay dan Pengaruh Variabel Pendapatan, Jumlah Tanggungan Rumah Tangga, Usia, Akses ke Sekolah Terhadap Pemilihan serta Pengembangan Strategi Pengelolaan Sekolah

2018 sudah mencapai Rp 5,8 triliun. Besarnya investasi yang masuk pada triwulan I 2018 masih didominasi negara sebesar 70\%, sedangkan sisanya 30\% berasal dari investor asing. Investasi di Semarang difokuskan pada perdagangan dan jasa, khususnya manufaktur. Peningkatan investasi akan meningkatkan jumlah perusahaan di Semarang.

Kota Semarang memiliki jumlah perusahaan terbanyak di Jawa Tengah yaitu sebanyak 3.735 perusahaan pada tahun 2017. Tingginya jumlah perusahaan tersebut belum mampu mengatasi tingginya angka pengangguran di Semarang yang dari tahun 2012 hingga 2015 mengalami peningkatan. Berdasarkan data Badan Pusat Statistik Kota Semarang tahun 2012 hingga 2015 jumlah pengangguran mengalami peningkatan. Pada tahun 2012 jumlah pengangguran sebanyak 46.081, pada tahun 2013 sebanyak 49.733, pada tahun 2014 sebanyak 68.978, dan pada tahun 2015 sebanyak 51.229 sekaligus merupakan jumlah pengangguran tertinggi dibandingkan kotakota lain di Jawa Tengah. Hal tersebut dapat dilihat pada Tabel 2.

Tabel 2 Jumlah Siswa di Indonesia berdasarkan Jenjang Pendidikan Tahun 2017/2018

\begin{tabular}{|c|r|}
\hline Jenis Sekolah & Jumlah Siswa \\
\hline SMK & 4.904 .000 \\
\hline SMA & 4.783 .600 \\
\hline SMP & 10.125 .700 \\
\hline SD & 25.486 .500 \\
\hline
\end{tabular}

Sumber: BPS Jawa Tengah, 2019

Pada Tabel 2 terlihat bahwa Kota Semarang memiliki jumlah penganggur tertinggi dibandingkan dengan lima kota di Jawa Tengah yang berjumlah 51.229 jiwa. Peningkatan jumlah pengangguran di Semarang didominasi oleh pengangguran lulusan SMA. Pengangguran lulusan SMA termasuk dalam jenis pengangguran ter- didik. Pengangguran terdidik terjadi karena belum adanya keselarasan antara perencanaan pembangunan pendidikan dan pengembangan lapangan kerja. Inilah penyebab utama dari jenis pengangguran ini. Faktanya institusi pendidikan di Indonesia hanya menghasilkan pencari kerja, bukan pencipta lapangan kerja (Sari AK, 2012).

Jumlah penganggur berpendidikan terakhir sekolah menengah atas di Semarang memiliki kontribusi yang paling tinggi dibandingkan dengan penganggur dengan pendidikan terakhir lainnya. Pada tahun 2015 kontribusi penganggur terhadap pendidikan terakhir sekolah menengah atas di Kota Semarang sebesar 37,59\%. Pengangguran terdidik terjadi karena belum adanya keselarasan antara perencanaan pembangunan pendidikan dan pengembangan lapangan kerja. Di sisi lain, penganggur berpendidikan ini lebih memilih formal laju pertumbuhan ekonomi yang tinggi di Semarang didukung oleh investasi di Semarang yang meningkat tajam. Kantor Penanaman Modal Satu Pintu (DPMPTSP) Semarang mencatat pencapaian investasi tersebut pada kuartal pertama pekerjaan dan mereka memiliki kemauan untuk bekerja di tempat yang secara langsung menempatkan mereka pada posisi yang baik dapat memperoleh banyak fasilitas dan langsung mendapatkan gaji pada posisi yang besar (Sari A.K., 2012).

Tabel 3 Total Unemployment di Lima Kota Besar di Jawa Tengah tahun 2015

\begin{tabular}{|l|c|}
\hline \multicolumn{1}{|c|}{ Kota } & Unemployment (People) \\
\hline Magelang & 3.927 \\
\hline Surakarta & 12.877 \\
\hline Salatiga & 5.794 \\
\hline Semarang & 51.229 \\
\hline Pekalongan & 6.131 \\
\hline Tegal & 10 \\
\hline
\end{tabular}

Kontribusi lulusan SMA tertinggi ini bertolak belakang dengan tren peningkatan jumlah 
SMA dan jumlah siswa SMA di Semarang. Jumlah SMA di Semarang mengalami peningkatan dari tahun ke tahun. Pada tahun 2008 jumlah SMA di Semarang hanya 75 sekolah kemudian meningkat 18,67\% menjadi 89 sekolah pada tahun 2016 (BPS, berbagai tahun). Bertambahnya jumlah SMA di Semarang menyebabkan bertambahnya jumlah siswa yang melanjutkan studi ke SMA di Semarang. Jumlah siswa SMA di Semarang mengalami peningkatan dari tahun ke tahun. Pada tahun 2008 jumlah siswa SMA sebanyak 33.262 orang kemudian meningkat 17,40\% menjadi 39.050 orang pada tahun 2016 (BPS, berbagai tahun).

Dalam rangka penyelenggaraan pendidikan baik di tingkat makro (negara) maupun di tingkat mikro (lembaga) yang dianggap penting adalah masalah pembiayaan yang merupakan unsur mutlak yang harus tersedia. Berdasarkan observasi awal yang dilakukan secara acak di sekolah menengah atas di Semarang diperoleh informasi bahwa besarnya sumbangan pengembangan pendidikan (SPP) untuk sekolah menengah atas negeri berada pada kisaran Rp 200.000,00 sampai Rp 350.000,00. Sedangkan untuk sekolah menengah atas swasta besaran bantuan pengembangan pendidikan (SPP) berada pada kisaran Rp 500.000,00 sampai Rp 1.500.000,00. Jumlah biaya beban di satu sisi dan nilai manfaat yang diperoleh dari pendidikan di sisi lain memengaruhi perilaku masyarakat secara keseluruhan dalam memilih jenis pendidikan dan pelatihan (Danim, 2003).

Permasalahan relatif tingginya biaya SPP siswa SMA yang harus ditanggung oleh rumah tangga namun terdapat fakta bahwa jumlah pengangguran terbanyak di Semarang adalah dari lulusan SMA sehingga menimbulkan keinginan penulis untuk melakukan penelitian apakah ada fakta bahwa biaya sekolah yang tinggi dan tingginya angka pengangguran lulusan SMA berdam- pak pada kesediaan rumah tangga untuk membayar biaya pendidikan SMA di Kota Semarang mengingat pembiayaan merupakan unsur mutlak yang harus tersedia.

\section{METODE PENELITIAN}

Penelitian ini merupakan penelitian deskriptif kuantitatif dengan menggunakan data primer yang diperoleh dari kuesioner responden yaitu orang tua siswa di SMA akreditasi A. Lokasi penelitian di Semarang. Jumlah sampel sebanyak 238 orang tua siswa SMA yang terakreditasi A dijadikan responden dalam penelitian ini, berdasarkan teknik snowball sampling.

Metode pengumpulan data yang digunakan dalam penelitian ini adalah metode observasi, studi pustaka, dokumentasi, dan angket. Metode analisis data dalam penelitian ini adalah dengan pendekatan contingent valuation method (CVM) dan analisis regresi linier berganda. Proses pelaksanaan untuk memperoleh nilai kesediaan untuk membayar terdapat lima tahapan menurut Fauzi, (2004), antara lain membangun hipotesis pasar, memperoleh nilai kesediaan untuk membayar, menghitung kesediaan untuk membayar nilai rata-rata, dan menjumlahkan data untuk mendapatkan nilai total kesediaan untuk membayar. Analisis regresi linier berganda digunakan untuk menentukan variabel yang memengaruhi kesediaan untuk membayar biaya pendidikan sekolah menengah atas di Kota Semarang. Persamaan model regresi linier berganda adalah sebagai berikut.

$$
\begin{aligned}
\mathrm{WTP}= & \text { alfa }+\beta_{1} \mathrm{PDPT}+\beta_{2} \mathrm{POT}+\beta_{3} \mathrm{JTRT} \\
& +\beta_{4} \mathrm{US}+\beta_{5} \mathrm{AKS}+\mathrm{e}_{\mathrm{i}}
\end{aligned}
$$

Keterangan:

$\mathrm{WTP}=$ Value of willingness to pay (kerelaan untuk membayar)

alfa $=$ Intercept 
Christina W.U., Metta P., Analisis Willingness to Pay dan Pengaruh Variabel Pendapatan, Jumlah Tanggungan Rumah Tangga, Usia, Akses ke Sekolah Terhadap Pemilihan serta Pengembangan Strategi Pengelolaan Sekolah

$\beta_{1-\mathrm{t}} \quad=$ Koefisien

PDPT = Pendapatan orang tua

POT $=$ Pendidikan orang tua

JRTRT $=$ Jumlah tanggungan dalam rumah tangga

US = Usia orang tua

AKS $=$ Akses ke sekolah

$\mathrm{e} \quad=$ Tingkat kesalahan

\section{HASIL DAN DISKUSI}

Secara geografis, Semarang berada di antara garis $6^{\circ} 50^{\circ}-7^{\circ} 10^{\prime}$ Lintang Selatan dan garis $109^{\circ} 35-110^{\circ} 50^{\prime}$ Bujur Timur. Pendekatan metode valuasi kontingen dalam penelitian ini digunakan untuk menganalisis tingkat kesediaan rumah tangga membayar pada SMA di Semarang. Kesediaan membayar diperoleh dengan menyebarkan kuesioner kepada 238 orang tua siswa di Kota Semarang. Setiap nilai kesediaan membayar yang diperoleh menunjukkan jumlah yang dibayarkan oleh rumah tangga. Dari 238 responden yang bersedia membayar biaya sekolah di SMA di Semarang. Nilai rata-rata kesediaan membayar responden Semarang dengan perbandingan nilai kesediaan membayar responden dengan jumlah total responden yang bersedia membayar sehingga diperoleh nilai rata-rata kesediaan membayar:

$\Sigma \mathrm{WTP}=\operatorname{Rp} \frac{133.050 .000,00}{238}$

$\sum \mathrm{WTP}=\operatorname{Rp} 559.034,00$

Berdasarkan hasil perhitungan menggunakan pendekatan metode penilaian kontinjen, dari jumlah responden sebanyak 238 orang tua siswa, secara keseluruhan responden bersedia membayar biaya sekolah menengah atas di Semarang. Untuk total nilai kesediaan membayar yang diperoleh adalah $\mathrm{Rp} 133.050 .000,00$ per bulan dengan nilai rata-rata kesediaan membayar $\mathrm{Rp}$ 559.034,00 per bulan. Nilai sebesar ini menunjukkan adanya kepedulian rumah tangga terhadap pendidikan anak sekolah menengah atas di Semarang.
Sedangkan pada Tabel 4 menunjukkan hasil regresi antara pendapatan, pendidikan orang tua, jumlah tanggungan rumah tangga, umur, dan lama akses. Berdasarkan hasil perhitungan yang telah dilakukan dengan menggunakan software Eviews 9, hasil yang diperoleh seperti yang ditunjukkan pada Tabel 4.

Tabel 4 Output of Multiple Linier Regression Analysis Results

\begin{tabular}{|l|r|c|}
\hline \multicolumn{1}{|c|}{ Variabel } & Koefisien & Prob \\
\hline C & -160.4 & 0.003 \\
\hline PDPT & 0.040 & 0.003 \\
\hline POT & 3.553 & 0.085 \\
\hline JTRT & 16.956 & 0.005 \\
\hline US & 3.219 & 0.002 \\
\hline AKS & -3.519 & 0.000 \\
\hline
\end{tabular}

Sehingga dihasilkan persamaan regresi:

$$
\begin{aligned}
\text { WTP }= & -160,4+0,040 \text { PDPT }+3,553 \text { POT }+ \\
& 16,956 \text { JTRT }+3,219 \text { US- 3,519 AKS }+e_{i}
\end{aligned}
$$

Berdasarkan hasil regresi linier berganda dapat disimpulkan sebagai berikut. Nilai konstanta -160,4 menandakan bahwa bila nilai semua variabel bebas adalah 0 (nol) maka nilai kesediaan membayar sebesar -160,4. Nilai koefisien variabel pendapatan (PDPT) adalah 0,036 dan bertanda positif $(+)$, artinya jika pendapatan seseorang bertambah seribu rupiah maka nilai WTP yang bersedia dibayar untuk biaya sekolah menengah atas di Semarang akan meningkat 36 rupiah dengan asumsi variabel independen lain dianggap konstan. Variabel pendidikan orang tua tidak memengaruhi nilai WTP. Nilai koefisien yang dimiliki variabel jumlah tanggungan rumah tanggungan keluarga (JTRS) adalah sebesar 16.956 dan bertanda positif (+). Artinya, jika jumlah tanggungan dari seseorang bertambah satu orang maka nilai WTP yang bersedia dibayar untuk biaya sekolah di SMA di Semarang akan meningkat sebesar Rp 16.956 dengan asumsi 
variabel bebas lainnya dianggap konstan. Koefisien variabel umur (US) memiliki nilai 3,219 dan bertanda positif $(+)$. Hal ini dapat diartikan bahwa jika usia seseorang bertambah satu tahun maka besarnya nilai WTP yang bersedia dibayar untuk biaya sekolah menengah atas di Semarang akan meningkat sebesar 3.219 rupiah dengan asumsi variabel independen lain dianggap konstan. Koefisien variabel akses (AKS) lama adalah 3.519 dan bertanda negatif (-), artinya jika lama akses dari rumah ke sekolah satu menit maka nilai WTP yang bersedia dibayar akan semakin berkurang sebesar 3.519 rupiah, dengan asumsi variabel independen lain dianggap konstan.

Berdasarkan hasil regresi yang diperoleh, variabel pendapatan (PDPT) memiliki pengaruh yang signifikan terhadap kemauan membayar (WTP) rumah tangga sekolah menengah atas di Semarang. Pendapatan (PDPT) di sini berdasarkan rupiah yang diperoleh rumah tangga selama satu bulan dari penghasilan yang diperoleh semua anggota rumah tangga. Hubungan yang memiliki variabel pendapatan dengan nilai WTP yang besar bertanda positif. Artinya, ketika pendapatan yang diterima rumah tangga meningkat maka jumlah kemauan membayar (WTP) rumah tangga tersebut akan meningkat. Hasil regresi yang diperoleh sesuai dengan teori yang mengatakan bahwa semakin tinggi pendapatan maka semakin besar pula nilai willingness to pay (WTP) yang harus dibayar (Simanjuntak, 2009; Li Jingru et al., 2018). Semakin tinggi pendapatan maka semakin tinggi capaian ekonominya sehingga semakin tinggi kemampuan dan kesempatan individu untuk mampu dan mau membayar biaya sekolah yang dibebankan oleh sekolah menengah atas di Kota Semarang. Responden yang berpenghasilan lebih tinggi memungkinkan untuk memiliki tingkat kemauan yang lebih tinggi mem- bayar biaya sekolah yang dibebankan dibandingkan dengan responden berpenghasilan rendah lainnya. Keynes menyatakan pendapatan merupakan variabel ekonomi yang sangat erat kaitannya dan penting dengan tingkat kemampuan seseorang dalam melakukan kegiatan konsumsi. Dalam hal ini sebagai upaya seseorang untuk memenuhi kebutuhan hidup dan meningkatkan taraf hidup keluarganya sehingga terdapat hubungan yang positif antara pendapatan dan konsumsi (Prasetyo, 2012). Semakin tinggi pendapatan yang dimiliki seseorang maka tingkat kemampuan mengonsumsi atau membayar juga dianggap semakin tinggi (Saptutyningsih, 2007). Hasil penelitian ini serupa dengan penelitian Rosyadi, Sasongko, \& Hoetoro (2016) tentang kesediaan rumah tangga membayar biaya pendidikan menengah unggul di Kota Malang, di mana penelitian tersebut menunjukkan bahwa variabel pendapatan rumah tangga berpengaruh positif dan signifikan atas kesediaan untuk membayar. Jika terjadi peningkatan pendapatan rumah tangga maka akan meningkatkan kemauan untuk membayar rumah tangga tersebut. Penelitian ini juga sesuai dengan penelitian yang dilakukan oleh Sari \& Setiartiti (2015), Li Jingru et al. (2018) kesediaan membayar untuk peningkatan kualitas pelayanan kereta api. Hasil penelitian ini menunjukkan bahwa tingkat pendapatan berpengaruh positif terhadap kesediaan membayar (WTP). Golbazi, et al. (2020). Hal ini disebabkan semakin tinggi tingkat pendapatan seseorang maka semakin mudah seseorang mengeluarkan uang untuk kebutuhan lain seperti untuk meningkatkan kualitas. Pengaruh yang terjadi antara pendapatan dan kemauan membayar diperkuat oleh penelitian Permata (2012) dan Li Jingru et al. (2018) yang menyatakan bahwa kesediaan untuk membayar secara umum dipengaruhi oleh beberapa faktor, salah satunya adalah pendapatan 
Christina W.U., Metta P., Analisis Willingness to Pay dan Pengaruh Variabel Pendapatan, Jumlah Tanggungan Rumah Tangga, Usia, Akses ke Sekolah Terhadap Pemilihan serta Pengembangan Strategi Pengelolaan Sekolah

konsumen dari pendapatan rumah tangga. Berdasarkan hasil penelitian Ekanem, Okon, \& Ekpoh (2012) juga disebutkan bahwa pungutan SPP bergantung pada kemampuan rumah tangga berdasarkan pendapatan yang diterima terhadap biaya pendidikan yang harus dikeluarkan selama siswa menempuh pendidikan. Jika pendapatan rumah tangga dapat menutupi anggaran untuk kebutuhan rumah tangga dan terutama biaya pendidikan maka rumah tangga tersebut akan bersedia membayar biaya pendidikan. Berdasarkan hasil di lapangan diketahui bahwa secara keseluruhan responden bersedia membayar karena sebagian besar responden memiliki tingkat pendapatan rata-rata Rp 3.750.000,00. Jumlah tersebut mendekati UMR Semarang yaitu Rp 2.715.000,00 yang artinya pada saat pendapatan tinggi, responden mampu secara finansial untuk membiayai sekolah. Hal ini pula yang menyebabkan tingginya minat masyarakat untuk melanjutkan ke sekolah menengah atas di Semarang.

Pendidikan orang tua merupakan pendidikan (POT) yang telah ditempuh oleh orang tua pada jenjang pendidikan formal di Indonesia. Diukur dalam satuan tahun, misalnya pendidikan dasar (6 dan 9 tahun), pendidikan menengah (12 tahun), dan pendidikan tinggi (15, 16, 18, dan 21 tahun). Hasil regresi menunjukkan bahwa variabel tingkat pendidikan tidak berpengaruh signifikan terhadap besar kemauan membayar (WTP) rumah tangga sekolah menengah atas di Semarang. Hasil penelitian ini berbeda dengan hasil penelitian Rosyadi, Sasongko, \& Hoetoro (2016) mengenai kesediaan rumah tangga membayar biaya pendidikan menengah unggul di Kota Malang, di mana dalam penelitian variabel pendidikan orang tua berpengaruh positif dan signifikan tentang kesediaan untuk membayar. Berdasarkan hasil penelitian Sadikin, dkk. (2017) dijelaskan bahwa terdapat perbedaan faktor-faktor yang memengaruhi besarnya kesediaan membayar karena perbedaan karakteristik sosial ekonomi masing-masing individu. Namun hasil penelitian ini didukung oleh penelitian Fildzah (2016), Walsh Sharon, et al. (2018), dan Golbazi, et al. (2020) tentang kesediaan membayar (WTP) fasilitas penyelenggara jaminan sosial kesehatan di Banda Aceh. Fildzah (2016) menyatakan bahwa variabel tingkat pendidikan tidak berpengaruh signifikan terhadap keinginan membayar. Hasil penelitian menjelaskan bahwa tidak terdapat pengaruh yang signifikan antara tingkat pendidikan terhadap keinginan membayar karena sampel yang relatif homogen. Berdasarkan hasil di lapangan diperoleh informasi bahwa sampel relatif homogen, dari total 100 responden terdapat 51 orang (51\%) yang tamat SMA/SMK/sederajat. Hal ini juga didukung oleh stigma yang tumbuh di masyarakat yaitu rumah tangga dengan kondisi sosial ekonomi menengah ke bawah cenderung menyekolahkan anaknya di sekolah menengah atas dengan harapan setelah lulus sekolah menengah atas anak tersebut akan segera mendapatkan pekerjaan dengan keterampilan yang dimilikinya. Selain itu, variabel tingkat pendidikan orang tua tidak berpengaruh signifikan terhadap kesediaan untuk membayar karena kesediaan untuk membayar orang tua dibatasi oleh biaya sumbangan pengembangan pendidikan (SPP) di sekolah menengah atas negeri dan swasta. Meskipun pendidikan orang tua tinggi tetapi jika anak responden bersekolah di SMAN kesediaan untuk membayar relatif rendah, walaupun responden berpendidikan rendah namun jika anak responden bersekolah di SMA swasta, kesediaan untuk bayarannya relatif lebih tinggi. Hal ini terjadi karena adanya perbedaan biaya iuran bantuan pendidikan antara SMA negeri dan swasta, yaitu SPP di SMA swasta relatif lebih mahal. 
Jumlah tanggungan (JTRT) adalah anggota rumah tangga yang tidak bekerja dan tidak memperoleh penghasilan. Kebutuhan sehari-hari dan kebutuhan lainnya seperti biaya pendidikan anggota rumah tangga yang tidak bekerja ditanggung oleh anggota rumah tangga yang bekerja dan berpenghasilan. Jumlah tanggungan suatu rumah tangga diukur berdasarkan jumlah orang dalam suatu rumah tangga. Anggota rumah tangga adalah banyaknya anggota keluarga atau orang lain yang tinggal dalam satu rumah. Berdasarkan hasil regresi diketahui bahwa variabel jumlah tanggungan rumah tangga berpengaruh signifikan terhadap kemauan membayar (WTP) rumah tangga sekolah menengah atas di Semarang. Hubungan yang dimiliki variabel jumlah tanggungan rumah tangga dengan kemauan membayar (WTP) bertanda positif, artinya semakin bertambahnya jumlah tanggungan rumah tangga maka kemauan membayar (WTP) rumah tangga akan meningkat.

Berdasarkan temuan di lapangan, variabel jumlah tanggungan rumah tangga berpengaruh positif terhadap kesediaan membayar karena rumah tangga yang menjadi responden memiliki rata-rata jumlah tanggungan dua dan tiga orang per rumah tangga, angka ini rata-rata tidak membebani pendapatan rumah tangga. Jika dilihat dari tingkat pendapatan rata-rata pendapatan responden adalah Rp 3.750.000,00. Jumlah tersebut mendekati UMK Semarang yaitu sebesar Rp 2.715.000,00 yang artinya pada saat pendapatan tinggi responden mampu secara finansial untuk membiayai sekolah. Hasil penelitian ini sesuai dengan Rosyadi, Sasongko, \& Hoetoro (2016); Li Jingru et al. (2018) tentang kesediaan rumah tangga membayar biaya pendidikan menengah unggul di Kota Malang, di mana dalam penelitian tersebut menunjukkan bahwa variabel terikat rumah tangga berpengaruh positif dan signifikan terhadap kesediaan untuk membayar rumah tangga. Pengaruh positif jumlah tanggungan karena rumah tangga di tiga lembaga pendidikan menengah terkemuka memiliki rata-rata jumlah tanggungan dua dan tiga orang per rumah tangga, jumlah tersebut ratarata tidak membebani pendapatan rumah tangga. Selain itu, tingginya ekspektasi rumah tangga terhadap pendidikan menengah unggul dari segi manfaat yang diperoleh baik jangka pendek maupun jangka panjang membuat rumah tangga rela mengorbankan asetnya untuk membiayai biaya pendidikan anggota rumah tangga guna memperoleh layanan pendidikan menengah unggul. Hasil penelitian ini diperkuat dengan hasil penelitian Cahyaningrum \& Iasmaini (2014) yang menyatakan bahwa jumlah anggota rumah tangga berpengaruh positif dan signifikan terhadap pengeluaran rumah tangga untuk pendidikan di Jawa Timur. Sedangkan Zuraidah (1999) berdasarkan hasil penelitian yang dilakukan oleh pegawai Institut Pertanian Bogor (IPB) menyatakan bahwa ketergantungan keluarga berpengaruh terhadap pengeluaran rumah tangga untuk pendidikan dan kesehatan.

Berdasarkan hasil regresi yang diperoleh, variabel umur (US) berpengaruh signifikan terhadap kemauan membayar (WTP) rumah tangga sekolah menengah atas di Kota Semarang. Usia digunakan untuk mengukur kematangan seseorang dalam pengambilan keputusan hubungan yang memiliki variabel usia dengan kesediaan untuk membayar (WTP) bertanda positif. Artinya, ketika orang tua menua meningkat, kemauan membayar (WTP) rumah tangga akan meningkat.

Hasil penelitian ini sejalan dengan penelitian yang dilakukan oleh Sari \& Setiartiti, (2015); Walsh Sharon, et al. (2018) tentang kesediaan membayar untuk peningkatan kualitas pelayanan kereta api dengan menggunakan metode contin- 
Christina W.U., Metta P., Analisis Willingness to Pay dan Pengaruh Variabel Pendapatan, Jumlah Tanggungan Rumah Tangga, Usia, Akses ke Sekolah Terhadap Pemilihan serta Pengembangan Strategi Pengelolaan Sekolah

gent valuation (CVM). Penelitian ini menunjukkan bahwa usia berpengaruh positif terhadap kesediaan untuk membayar (WTP). Hal ini disebabkan semakin bertambahnya usia seseorang, semakin luas pula cara berpikir dalam memahami pentingnya kualitas pelayanan. Hasil penelitian ini juga senada dengan penelitian yang dilakukan oleh Sasmi (2016) yang menjelaskan bahwa variabel usia berpengaruh positif dan signifikan terhadap kesediaan membayar. Berdasarkan temuan di lapangan, responden secara keseluruhan bersedia membayar uang sekolah di SMA karena usia responden masih tergolong usia produktif, tidak ada responden yang melebihi usia produktif 64 tahun.

Akses ke sekolah (AKS) adalah waktu tempuh siswa dari rumah ke sekolah yang diukur dengan menit. Berdasarkan hasil estimasi model regresi menunjukkan bahwa variabel lama akses sekolah berpengaruh signifikan terhadap kemauan membayar (WTP) rumah tangga sekolah menengah atas di Semarang. Hubungan antara variabel lama akses dengan kemauan membayar (WTP) rumah tangga adalah negatif. Artinya, saat waktu tempuh berangkat ke sekolah maka kemauan membayar (WTP) rumah tangga di sekolah menengah atas di Semarang akan menurun. Hasil penelitian ini sesuai dengan penelitian yang dilakukan oleh Rosyadi, Sasongko, \& Hoetoro (2016); Li Jingru et al. (2018) tentang kesediaan rumah tangga untuk membayar biaya pendidikan menengah unggul di Malang, di mana dalam penelitian tersebut menunjukkan bahwa akses ke sekolah berpengaruh negatif dan signifikan terhadap kesediaan untuk membayar. Pengaruh variabel akses terhadap kesediaan untuk membayar menunjukkan hasil yang sama dengan penelitian yang dilakukan oleh Gertler \& Glewwe (1990) di pedesaan Peru yang dalam penelitian tersebut menyatakan bahwa rumah tangga bersedia membayar biaya pendidikan jika ada lembaga pendidikan menengah di desanya atas permintaan rumah tangga untuk mengurangi waktu tempuh ke sekolah. Semakin dekat jarak sekolah ke sekolah menengah maka kemauan untuk membayar rumah tangga semakin meningkat, karena sebagian besar siswa sekolah menengah bekerja membantu orang tua sebagai petani. Jika waktu tempuh ke sekolah semakin dekat maka siswa memiliki lebih banyak waktu untuk membantu orang tua bekerja sebagai petani. Hasil penelitian ini juga diperkuat dengan penelitian yang dilakukan oleh (Saqib, 2004); Walsh Sharon, et al. (2018) tentang kesediaan untuk membayar (WTP) di sekolah dasar di pedesaan Pakistan. Studi tersebut menunjukkan bahwa akses waktu tempuh ke sekolah berpengaruh pada kesediaan untuk membayar orang tua di pedesaan Pakistan. Semakin dekat waktu tempuh ke sekolah, semakin besar keinginan orang tua untuk menyekolahkan anaknya di sekolah dasar. Temuan ini sesuai dengan hasil di lapangan, orang tua akan memilih SMA yang lebih dekat dengan rumah, karena jika jarak dari rumah ke sekolah lama maka rumah tangga akan mengeluarkan biaya yang tidak sedikit. Misalnya, biaya hidup seorang anak jika jarak ke sekolah tidak memungkinkan setiap hari dari rumah. Menurut Khasanah (2012) dalam penelitiannya tentang pengambilan keputusan orang tua dalam memilih sekolah dasar diperoleh fakta bahwa lokasi sekolah berpengaruh terhadap keputusan memilih sekolah. Penilaian lokasi sekolah adalah jarak tempuh, transportasi, dan keamanan serta kenyamanan pergi ke sekolah sehingga pengaruh positif lokasi sekolah dapat diperoleh atas keputusan orang tua. Penilaian lokasi dan akses sekolah pada hasil penelitian ini sama-sama berpengaruh, orang tua akan sangat mempertimbangkan lokasi atau akses 
sekolah dalam menentukan lembaga pendidikan untuk anaknya. Berdasarkan temuan di lapangan, responden secara keseluruhan bersedia membayar karena rata-rata lama waktu akses responden ke sekolah \pm 30 menit sehingga responden tidak mengalokasikan tambahan dana yang terlalu banyak biaya berupa biaya transportasi anakanak (siswa) ke sekolah.

\section{KESIMPULAN}

Berdasarkan hasil perhitungan dan pembahasan, kesimpulan yang dapat diambil dalam penelitian ini adalah nilai rata-rata kesediaan untuk membayar (WTP) rumah tangga sekolah menengah atas di Kota Semarang adalah $\mathrm{Rp}$ 559.034,00 per bulan dan variabel yang berpengaruh signifikan terhadap kesediaan membayar (WTP). Jumlah rumah tangga di sekolah menengah atas adalah variabel pendapatan, jumlah tanggungan rumah tangga, usia, dan lama akses, sedangkan variabel yang tidak memengaruhi kesediaan membayar (WTP) rumah tangga SMA di Semarang adalah variabel pendidikan orang tua.

\section{DAFTAR RUJUKAN}

BPS. 2017. Central Java in Figures 2017. Semarang: BPS.

BPS. 2017. Indonesian Statistics 2017. Jakarta: BPS. Danim, S. (2003). Human Resource Economics. Bandung: Loyal Library.

BPS. 2017. Semarang in Figures 2017. Semarang: BPS.

Cahyaningrum, N.I. \& Iasmaini, Z. 2012. Tobit

Regression Approach to Factors Affecting Household Expenditures for Education in East Java. (http//www.digilib.its.ac.id). Downloaded on February 18, 2018.
Ekanem, E.E., Okon, J.E., \& Ekpoh, U.I. 2012. Reforming Education through User Fees: Ability and Willingness to Pay for University Education in Calabar, Nigeria. Journal of Education and Practice, 3 (8).

Fauzi, A. 2004. Economy of Natural Resources and Environment. Jakarta: Main Gramedia Library.

Fildzah, S. 2016. Willingness to Pay (WTP) Facility of Health Social Security Organizing Agency in Banda Aceh. Essay. Banda Aceh: Syah Kuala University.

Gertler, P. \& Glewwe, P. (1990). The Willingness to Pay for Education in Developing Countries Evidence from Rural Peru. Journal of Public Economics, 251-275.

Golbazi, Arel El Danaf, \& Can B. Aktas. (2020). Willingness to pay for green buildings: A survey on students' perception in higher education. Energy and Building, Vol. 216.

Khasanah, N. 2012. Factors Affecting Parents in Decision Making Choosing Private Primary Schools (SD Virgo Maria 2 and SDIP. H. Soebandi Bawen District, Semarang Regency). Satya Widya, 28(2), 137146.

Li Jingru, Jian Zuo, Hong Guo, Gaihong He, \& Han Liu. 2018. Willingness to pay for higher construction waste landfill charge: A comparative study in Shenzhen and Qingdao, China. Waste Management, 81, 226-233.

Ngadi. 2014. Relevance of Vocational Education to the Labor Market in Indonesian. The Indonesian Population Journal, 9(1).

Nihayah, D.M. \& Kusumantoro. 2010. Determinants of Regional Wages: Skilled Labor and Uneducated Labor in Indonesia. JEJAK, 28-39.

Nurtanto, M. \& Ramdani, S.D. 2016. Preparing Vocational Education Based on Local Wis- 
Christina W.U., Metta P., Analisis Willingness to Pay dan Pengaruh Variabel Pendapatan, Jumlah Tanggungan Rumah Tangga, Usia, Akses ke Sekolah Terhadap Pemilihan serta Pengembangan Strategi Pengelolaan Sekolah

dom, 1(1), 59-66. Yogyakarta: Yogyakarta State University.

Nurtanto, M. 2015. Implementation of Problem

- Based Learning Based Basic Compensation of Conventional Ignition Systems to Improve Cognitive, Psychomotor, and Affective Learning Outcomes of Ma'arif Salam Vocational School Students. In Thesis.

Permata, M.R. 2012. Ability to Pay Analysis and Willingness to Pay for Soekarno Hatta Manggarai Railway Service Users. Thesis. Depok: UI (University of Indonesia).

Prasetyo, P.E. 2012. Macroeconomic Fundamentals. Yogyakarta: Yogyakarta Beta Offset.

Rosyadi, M.I., Sasongko, \& Hoetoro, A. 2016. Willingness to Pay Households in Paying for Superior Middle Education Fees in Malang. Journal of Economics and Development Studies, 8(2).

Sadikin, P.N., Mulatsih, S., Pramudya, B., \& Arifin, H.S. 2017. Willingness to Pay Analysis on Mount Rinjani National Park Ecotourism. Journal of Forestry Policy Analysis, 31-46.

Saptutyningsih, E. 2007. Influential Factors Against Willingness to Pay For Improvement of Code River Water Quality in Yogyakarta. Journal of Economics and Development Studies, VIII(2), 171-182.

Saqib, N.U. 2004. Willingness to Pay for Primary Education in Rural Pakistan. The Pakistan Development Review, 43(1), 7751.

Sari, A.K. 2012. Analysis of the Effect of Education Levels, Economic Growth, and Wages on Educated Unemployment in West
Sumatra. Journal of Development Economics.

Sari, H.P. \& Setiartiti, L. 2015. Willingness to Pay Improved Railway Service Quality. Journal of Economics and Development Studies, 16(2), 200-209.

Sasmi, N.A. 2016. Factors Affecting Willingness to Pay Visitors to Goa Cemara Beach Tourism Object Using the Contingent Valuation Method (CVM). Essay. Yogyakarta: Muhammadiyah University of Yogyakarta. Sharon W., Cullinan, J., \& Flannery, D. 2018. Exploring Heterogenity in Willingness to Pay for the Attributes of Higher Education Institutions. Oxford Economic Papers, 1-22 doi: 10.1093/oep/gpy030.

Simanjuntak, G.E.M. 2009. Willingness to Pay Society Analysis of Improvement of Service of Water Supply System with WSLC (Water Study of Low Income Community) (Case Study of Situdaun Village, Tenjolaya District, Bogor Regency). Thesis. Bogor: IPB (Bogor Agricultural Institute).

Susanti, A. \& Nihayah, D.M. 2019. Economics Development Analysis Journal, 8(2). Yogyakarta: Yogyakarta State University.

Susiani, R. 2009. Study of the International Standard School (SBI) of SMA Negeri 2 Salatiga and Its Relationship in the Development of Surrounding Areas. In Thesis. Semarang: Diponegoro University.

Zuraidah, Y. 1999. Economic Crises Influence on Expenditures for Education and Family Health (Study of Civil Servants at the Bogor Agricultural Institute). Essay. Bogor: IPB (Bogor Agricultural Institute). 